\title{
Enzyme assays in diseases of erythrocytes
}

\author{
T. A. J. PRANKERD
}

From the Department of Clinical Haematology, University College Hospital Medical School, London

The human red cell has been the source of a great deal of information in medical science. It has provided evidence of genetic variation in natural populations and of the molecular basis of diseases in the case of abnormal haemoglobin, and it has been a model for studying a number of inherited diseases including those peculiar to the cell itself. It is the latter which is dealt with here.

The erythrocyte is a relatively uncomplicated cell in which metabolic reactions have become highly adapted to function. In addition to its major constituent haemoglobin, it contains a complement of glycolytic enzymes, some residual enzymes from the tricarboxylic acid cycle, and a series of enzymes forming the pentose phosphate pathway. It is probably true that the limited energy requirements of the cell are provided by glycolysis, whilst a 'reduction potential' which protects against oxidation, especially of haemoglobin, is maintained through the pentose pathway. In the case of glycolysis the energy formed is stored principally in the form of ATP whilst the reduction capacity of the cell exists principally in the form of reduced glutathione. Highly developed in the red cell is an enzyme system for the reduction of methaemoglobin. The interaction of these various metabolic pathways is shown in Figure 1. Abnormal enzyme function, which may be due to a lack of normal enzyme, or the

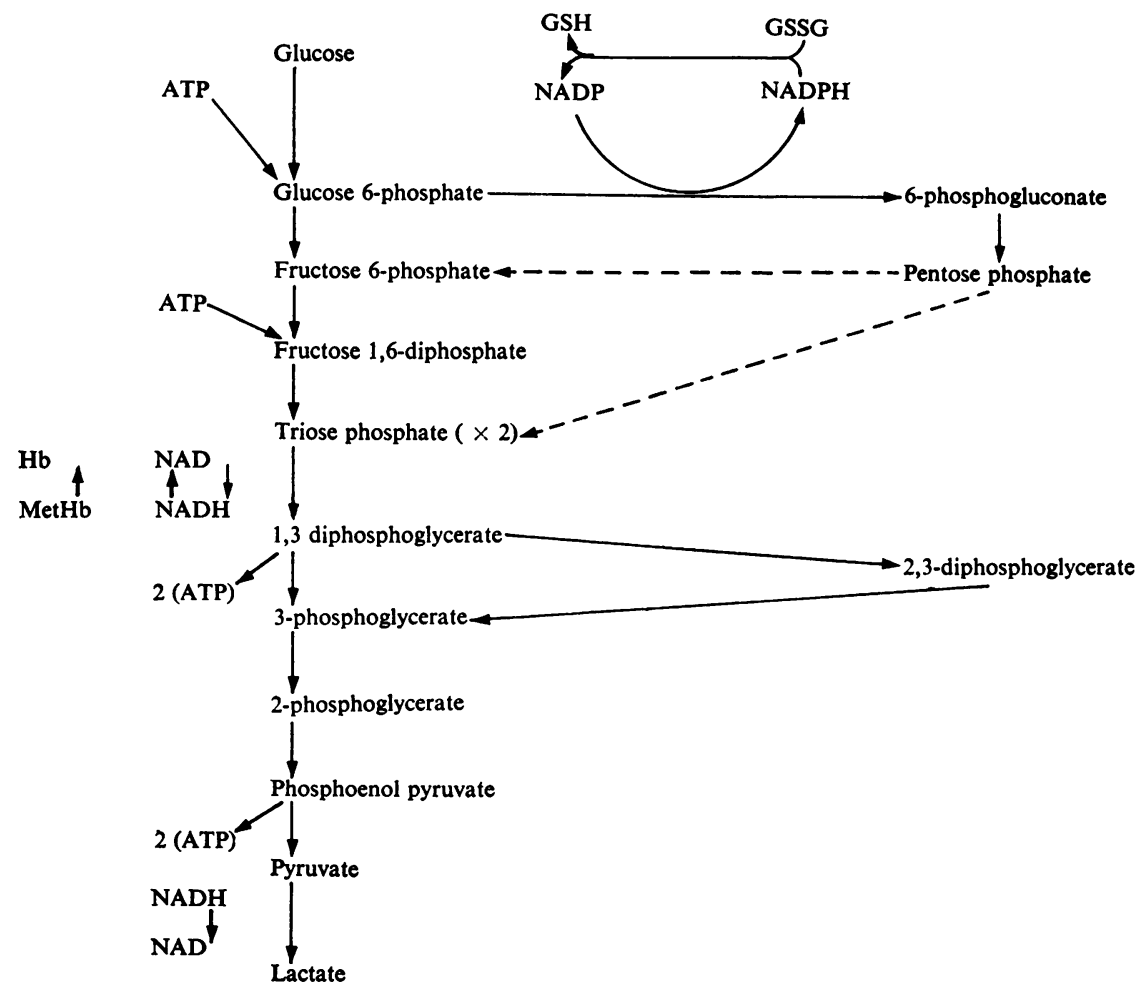

Fig. Major metabolic pathways in the erythrocyte. 
presence of an abnormal enzyme or an unstable one, has been found in both of the principal metabolic pathways and it is often associated with a susceptibility to an increased destruction of the cell itself. When this occurs the disorder forms part of a group of diseases known as the 'congenital nonspherocytic haemolytic anaemias'.

The following glycolytic defects of the red cell have been found and their existence in the main confirmed: hexokinase (EC 2.7.1.1) (Valentine, Oski, Paglia, Baughan, Schneider, and Naiman, 1967); glucose phosphate isomerase (EC 5.3.1.9) (Baughan, Valentine, Paglia, Ways, Simons, and de Marsh, 1967); triose phosphate isomerase (EC 5.3.1.1) (Schneider, Valentine, Hattori, and Heins, 1965); diphosphoglyceromutase (EC 2.7.5.4) (Bowdler and Prankerd, 1964); phosphoglycerate kinase (EC 2.7.2.3) (Kraus, Langston, and Lynch, 1968); and pyruvate kinase (EC 2.7.1.40) (Valentine, Tanaka, and Miwa, 1961).

Of these deficiencies that of pyruvate kinase appears to be much the most common and outnumbers the others by about five to one. It can be detected by a relatively simple enzyme assay in which the pyruvate kinase reaction is coupled with that of lactate dehydrogenase (EC 1.1.1.27) and the rate of conversion of NADH to NAD is measured at 340 nm (Tanaka, Valentine, and Miwa, 1962). It is important to use two concentrations of phosphoenolpyruvate $(0.0075$ and $0.015 \mathrm{M})$ as the kinetics of at least two enzyme variants differ, and it should be remembered that the diluted haemolysate is unstable. As leucocyte pyruvate kinase activity is several hundred times that of red cells great care should be taken to remove all white cells while centrifuging and washing the red cells. Removal of most of the reticulocytes at the same time as the leucocytes avoids falsely high enzyme activity in patients with a marked reticulocytosis. Affected patients have $5-20 \%$ of normal activity. Screening procedures depending on $p \mathrm{H}$ change (Brunetti and Nenci, 1964) resulting from the formation of lactic acid, or the UV fluorescence of NADH (Beulter, 1966), have been described.

The metabolic consequences of this enzyme defect are an increase in 2,3-diphosphoglycerate (Bowdler and Prankerd, 1964), and a fall in cell ATP which may be causally related to the haemolytic instability of the cell. The clinical picture is of a chronic haemolytic anaemia from birth producing a wide range of haemoglobin levels and unremarkable red cell morphology. Reticulocyte counts are high and increase after splenectomy which has only a marginally beneficial effect on the patient. The disease is predominant amongst northern Europeans and only appears in homozygotes. Genetic variants of pyruvate kinase are being described but few have 胥t been fully identified (Paglia, Valentine, Baughan, Miller, Reed, and McIntyre, 1967).

The intermediate phosphate compound 2;3diphosphoglycerate (2,3-DPG) is of special interest in the red cell because of its interaction with haemglobin. Other phosphate compounds such as AEP also interact with haemoglobin producing alteration in its oxygen dissociation, but the major effects seem to result from changes in concentration of 2,3-DPG An increase in this compound shifts the curve to the right and a decrease shifts it to the left; the degree $\overrightarrow{\otimes f}$ shift obtained can produce significant alterations 荡 oxygen delivery to the tissues. This mechanish therefore contributes an internal compensatowy mechanism against the anoxia of anaemia (Bellingha्d and Huehns, 1969) and has now been demonstrated in a number of diseases (Huehns, 1970). The problêm of special interest here is the control of 2,3-DPG concentration in conditions other than pyruvate kinase deficiency, where no enzyme defect is present.

Defects involving the reduction system within the red cell include the following: glucose 6-phosphate dehydrogenase (EC 1.1.1.49, G6PD) (Carson, Flanagan, Ickes, and Alving, 1956); phosphoglucenate dehydrogenase (EC 1.1.1.43, PGD) (Lausecke্ु, Heidt, Fisher, Hartley, and Lohr, 1966); glutathgone reductase (EC 1.6.4.2) (Carson, Brewer, and leses, 1961); glutathione peroxidase (EC 1.11.19) (Necheles, Boles, and Allen, 1968); glutathione deficiency (国部, Loos, and Prins, 1961).

Amongst this group by far the most comm deficiency is of course G6PD which may have an incidence of $20 \%$ or more amongst some populatio

Glucose 6-phosphate dehydrogenase catalyses the initial step in the pentose phosphate pathway a a thereby results in the generation of NADPH. In the mature red cell, lacking the full enzyme complement of the Krebs cycle, NADPH cannot be formed in agy other way. It is important to the cell in maintainiug adequate concentrations of reduced glutathione which in turn protects from oxidation the other SH groups of haemoglobin and the cell membrane. Normally about $10 \%$ of glucose is utilized in the pentose phosphate pathway.

Glucose 6-phosphate dehydrogenase deficiency 75 readily detected by assay of the rate of formation of NADPH at $340 \mathrm{~nm}$ in a haemolysate with glucose 6-phosphate as the substrate. Once again leucocytes and reticulocytes should be removed first by centyfuging. This method of assay also measures phosphigluconate dehydrogenase and if a separate assay required then a two-step procedure, with separase substrates, should be employed. A variety of methods have been proposed as screening procedures agd make use of such adjuncts as the reduction कf 
brilliant cresyl blue, methaemoglobin, or a tetrazolium compound (World Health Organization, 1967).

Glucose 6-phosphate dehydrogenase has been studied in considerable detail and some 40 biochemical variants have been described differing in their electrophoretic mobility, kinetic variations, or heat lability. Variants associated with normal enzyme activity (eg, A) are of no clinical significance, whilst others (eg, A - ) in which enzyme activity is diminished, lead to haemolysis provoked by drugs (Table); yet others, which result in severe instability of the enzyme protein, are associated with a congenital nonspherocytic type of haemolytic anaemia.

\begin{tabular}{|c|c|}
\hline $\begin{array}{l}\text { 8-Aminoquinolines } \\
\text { Primaquine } \\
\text { Pamaquine } \\
\text { Pentaquine } \\
\text { Chloroquine }\end{array}$ & $\begin{array}{l}\text { Sulfones } \\
\text { Sulfoxone } \\
\text { Diaminodiphenyl-sulfone } \\
\text { Thiazosulfone }\end{array}$ \\
\hline $\begin{array}{l}\text { Sulphonamides } \\
\text { Sulphanilamide } \\
\text { Sulphamethoxypyridazine } \\
\text { Salicylazosulphapyridine } \\
\text { Sulphacetamide } \\
\text { Acetylphenylhydrazine } \\
\text { Acetanilid } \\
\text { Acetophenetidin } \\
\text { Antipyrine } \\
\text { Acetylsalicylic acid } \\
\text { Naphthalene derivatives } \\
\text { Ascorbic acid } \\
\text { Quinidine } \\
\text { Trinitrotoluene }\end{array}$ & $\begin{array}{l}\text { Nitrofurans } \\
\text { Nitrofurantoin } \\
\text { Furazolidone } \\
\text { Nitrofurazone } \\
\\
\text { Pyramidone } \\
\text { Acute bacterial infections } \\
\text { Viral infections } \\
\text { Diabetic ketosis } \\
\text { Para-aminosalicylic acid } \\
\text { Methylene blue } \\
\text { Probenecid } \\
\text { Quinine } \\
\text { Fava bean }\end{array}$ \\
\hline
\end{tabular}

Table Agents reported to cause destruction of red cells deficient in glucose 6-phosphate dehydrogenase

The enzyme appears to be located on the $\mathrm{X}$ chromosome and we therefore find homozygous females and hemizygous males most affected by its deficiency. Glucose 6-phosphate dehydrogenase activity declines with the aging of normal red cells, and the variations observed in the severity of the clinical state associated with deficiency of the enzyme are probably determined by a difference in the stability of each particular enzyme variant although in some cases it is possible that there is an actual deficit of enzyme protein (eg, A - individuals). Thus we find grades of clinical affection, the A - type being susceptible only to a limited number of drugs, whilst the mediterranean and south east Asian types are sensitive to the same drugs and also to infection, the effects of the fava bean and haemolytic disease of the newborn; the northern European type is associated with chronic haemolytic anaemia from birth.

The haemolytic anaemia affecting all except north Caucasians is intermittent and related to the administration of some offending drug (Table). In negroes the haemolysis is self-limiting but this may not be so in Mediterraneans. Diagnosis can be made by enzyme assay but it should be realized that this may be normal soon after a haemolytic episode because the surviving cells are all young, and the diagnosis may then have to await the development of a remission or depend on family studies.

Reduced glutathione is probably involved in the protection of both haemoglobin and the red cell membrane against oxidative damage; two enzymes, catalase (EC 1.11.1.6), and glutathione peroxidase, which are both present in the red cell, are involved in the elimination of peroxides. A deficiency of reduced glutathione in the red cell tends to result in the production of Heinz bodies in the presence of oxidative agents in vitro, but these may not be apparent during a haemolytic episode in vivo. Although a deficiency of reduced glutathione occurs as a result of G6PD deficiency, it also may be due to a deficiency of glutathione synthesis resulting from deficiencies of glutathione reductase and phosphogluconate dehydrogenase. Unlike the majority of cases of G6PD deficiency these other disorders appear to be associated with moderately severe forms of congenital nonspherocytic haemolytic anaemia in which drug exacerbation is not always apparent. Deficiency of catalase or glutathione peroxidase has no adverse effect on red cell survival unless both deficiencies are present in the same individual.

The other important enzyme with pathological associations in the red cell is methaemoglobin reductase. This enzyme is responsible for the reduction of methaemoglobin which forms in the cell spontaneously, and without a suitable reducing system the red cell would soon become functionless. The deficiency state results in the accumulation of methaemoglobin and the presence of persistent cyanosis and moderate erythrocytosis. The activity of this enzyme in reducing methaemoglobin is maintained by glycolysis through a redox coenzyme system involving NADH. The system appears to be geared to the phosphorylation of glyceraldehyde 3-phosphate (Fig. 1).

This deficiency can be differentiated from the presence of unstable haemoglobin (Hb-M) by haemoglobin electrophoresis and by assay of the enzyme. The assay depends on the reduction of an indophenol dye to a colourless form by the NADHmethaemoglobin reductase complex (Scott, 1960). The substrate used in this assay is not methaemoglobin because the reaction time is very much shorter with the dye. Differentiation from acquired methaemoglobinaemia is not difficult as this is not lifelong and disappears rapidly after the offending agent has been removed. The deficiency is inherited as an autosomal character presenting in homozygotes. It 
is probably a heterogeneous disorder and different species of abnormal enzymes have been detected by starch gel electrophoresis (West, Gomperts, Huehns, Kessel, and Ashby, 1967). There is also clinical heterogeneity, some patients having mental deficiency which does not obviously correlate with the degree of methaemoglobinaemia. All patients appear to lose their cyanosis when treated with methylene blue.

Many other enzyme deficiencies can be demonstrated in red cells and in some of them the deficiency is part of a generally distributed cellular deficiency. Deficiencies of catalase, galactose-phosphate uridyl transferase (EC 2.7.7.10), argininosuccinate synthetase (EC 4.3.2.1) are examples. In these states the functional activity of the red cell does not appear to be jeopardized although diminished red cell survival may occur in untreated galactosaemia.

Acetylcholinesterase (EC 3.1.1.7) is of interest in that its activity is reduced in the red cells of patients with paroxysmal nocturnal haemoglobinuria and pernicious anaemia, but the exact significance of this finding is not clear (Auditore and Hartmann, 1959). An inherited deficiency has been described but without any haemolytic condition (Jones, 1962), and the enzyme can be inhibited by drugs without resulting in haemolysis (Metz, Stevens, van Rensburg, and Hart, 1961).

From a genetic point of view other red cell enzymes have been of interest in the assessment of the extent or character of genetically determined enzyme variations. Widespread polymorphism has been demonstrated in population studies of acid phosphatase (EC 3.1.3.2), carbonic anhydrase (EC 4.2.1.1), and adenylate kinase (EC 2.7.4.3). It is interesting that some polymorphic variations detected by electrophoresis are associated with altered enzyme activity (Harris, 1966). Up to date no attempts have been made to correlate these quantitative differences with any change in red cell function but this work is now occupying our attention.

\section{References}

Auditore, J. V., and Hartmann, R. C. (1959). Paroxysmal nocturnal hemoglobinuria. Erythrocyte acetylcholinesterase defect. Amer. J. Med., 27, 401-410.

Baughan, M. A., Valentine, W. N., Paglia, D. E., Ways P. O., Simons, E. R., and De Marsh, Q. B. (1967). Hereditary hemolytic anemia associated with glucosephosphate isomerase (GPI) deficiencya new enzyme defect of human erythrocytes. Blood, 30, 850, and (1968). Blood, 32, 236-249.

Bellingham, A. J., and Huehns, E. R. (1969). Oxygen dissociation in red cells from patients with abnormal haemoglobins a pyruvate kinase deficiency. Forsvarsmedicin, 5, 207-211.

Beutler, E. (1966). A series of new screening procedures for pyruvife kinase deficiency, glucose-6-phosphate dehydrogenase deficiency, and glutathione reductase deficiency. Blood, 553-562.

Bowdler, A. J., and Prankerd, T. A. J. (1964). Studies in congeni non spherocytic haemolytic anaemias with specific enzyme defects. Acta haemat. (Basel), 31, 65-78.

Brunetti, P., and Nenci, G. (1964). A screening method for detection of erythrocyte pyruvate kinase deficiency. Enz. 选 biol. clin., 4, 51-57.

Carson, P. E., Brewer, G. J., and Ickes, C. E. (1961). Decreas, glutathione reductase with susceptibility to hemolysis. Lab. clin. Med., 58, 804.

Carson, P. E., Flanagan, C. L., Ickes, C. E., and Alving, A. S. (1956). Enzymatic deficiency in Primaquine sensitive erythrocyler. Science, 124, 489.

Harris, H. (1966). Enzyme polymorphism in man. Proc. roy. Soc. $\overrightarrow{\vec{B}}$ 164, 288-310.

Huehns, E. R. (1970). Biochemical compensation in anaemia. Ls. sci. Basis Med., in the press.

Johns, R. J. (1962). Familial reduction in red cell cholinesterase. Noj" Engl. J. Med., 267, 1344-1348.

Kraus, A. P., Langston, M. F., Jr., and Lynch, B. L. (1968). Red الم المه phosphoglycerate kinase deficiency; a new cause of nònspherocytic hemolytic anaemia. Biochem. Biophys. $R$ u. Commun., 30, 173-177.

Lausecker, C., Heidt, P., Fischer, P., Hartleyb, H., and Lohr, G. $₫$. (1965). Anémie hemolytique constitutionelle avec déficit $\gtrless_{n}$ 6-phospho-gluconate-deshydrogénase. Arch. franc. Pediat. 22, 789-797.

Metz, J., Stevens, K., Rensburg, N. J. van, and Hart, D. (196( ) Failure of in vivo inhibition of acetylcholinesterase to affect erythrocyte life span; the significance of the enzyme defectinn paroxysmal nocturnal haemoglobinuria. Brit. J. Haemat. $458-463$.

Necheles, T. F., Boles, T. A., and Allen, D. M. (1968). Erythrgc glutathione peroxidase deficiency and hemolytic disease the newborn infant. J. Pediat., 72, 319-324.

Oort, M., Loos, J. A., and Prins, H. K. (1961). Hereditary absente reduced glutathione in the erythrocytes-a new clinic a d biochemical entity? (Preliminary communication) Vox (Basel), 6, 370-373.

Paglia, D. E., Valentine, W. N., Baughan, M. A., Miller, D. R., Ref్, C. F., and McIntyre, O. R. (1967). Identification of an iszyme of erythrocyte pyruvate kinase $(\mathrm{PK})$ responsible for hefe ditary hemolytic anaemia. Blood, 30, 881-882.

Schneider, A. S., Valentine, W. N., Hattori, M., and Heins, H. L. (1965). Hereditary hemolytic anemia with triosephospha isomerase deficiency. New Engl. J. Med., 272, 229-235.

Scott, E. M. (1960). The relation of diaphorase of human erythroct to inheritance of methemoglobinemia. J. clin. Invest., 39 , 1176-1179.

Tanaka, K. R., Valentine, W. N., and Miwa, S. (1962). Pyruve kinase deficiency-hereditary non-spherocytic hemolyeic anemia. Blood, 19, 267-295.

Valentine, W. N., Oski, F. A., Paglia, D. E., Baughan, M. Schneider, A. S., and Naiman, J. L. (1967). Hereditकy hemolytic anemia with hexokinase deficiency; role $3 \mathrm{f}$ hexokinase in erythrocyte aging. New Engl. J. Med., 276, 1-T1.

Valentine, W. N., Tanaka, K. R., and Miwa, S. (1961). A specific erythrocyte glycolytic enzyme defect (pyruvate kinase) in theee subjects with congenital non-spherocytic hemolytic anenta. Trans. Ass. Amer. Phycns., 74, 100-110.

West, C. A., Gomperts, B. D., Huehns, E. R., Kessel, I., and Ash $\overline{\bar{K}}$. J. R. (1967). Demonstration of an enzyme variant in a casedf congenital methaemoglobinaemia. Brit. med. J., 4, 212-214.

World Health Organization (1967). Standardisation of procedures Agr the study of glucose 6-phosphate dehydrogenase Wld Hlth techn. Rep. Ser., 366. 